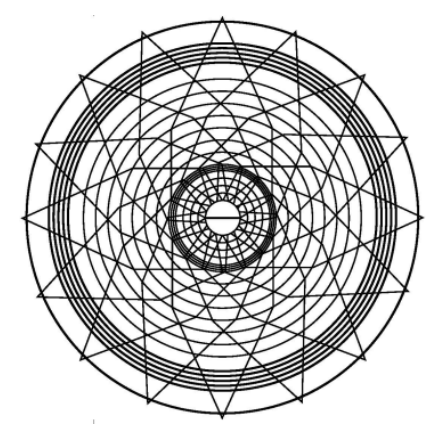

\title{
THE REPRESENTATION OF THE FEDERAL ELECTIONS OF 2011 AND 2012 IN RUSSIA BY THE MAJOR NATIONAL TELEVISION CHANNELS
}

\author{
Davydov S. \\ School of Media, Faculty of Communications, Media and \\ Design, National Research University Higher School of \\ Economics (Moscow) \\ sdavydov@hse.ru \\ Logunova O. \\ Department of General Sociology, School of Sociology, \\ Faculty of Social Sciences, National Research University \\ Higher School of Economics (Moscow) \\ ologunova@hse.ru
}

\begin{abstract}
:
The programs of Russian TV channels in the context of electoral campaigns have repeatedly been selected as a subject of social surveys. The proposed paper is based on the results of content analysis of informational programs of the three major channels Pervij, Rossija-1 and NTV - during the Duma campaign of 2011 and the presidential campaign of 2012. The research findings demonstrate the thematic and contextual features of the programs, tones and mentioned persons. It is shown that the representation of the electoral competition was mostly imitative. The governing party ("United Russia") and the authorities' candidate (Vladimir Putin) were presented mostly as officials at work, which gave them certain advantages.

There were no principal differences in the position of various channels towards the political process. In both cases public political activity increased noticeably after voting: in November 2011 in the form of protest demonstrations, and later in March 2012 in the form of protest and supportive demonstrations.
\end{abstract}

Keywords: content analysis, Russian television, elections in Russia, Putin, “United Russia"

\section{Introduction}

Elections are a favourite topic for analysis among political scientists and representatives of different disciplines, such as psychology, philosophy, political science and sociology, who try to explain the reason for different types of personal choice and motivation for voting. However, the process is still not fully understood 


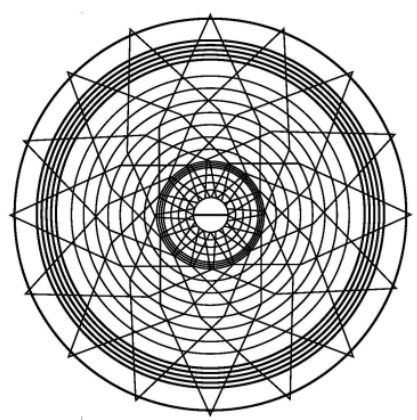

because each case seems to be unique and requires special attention from the researchers.

The media, such as television, radio and Internet, play significant roles in the formation of public opinion (Grushin, 1985). Taking into account the size of the Russian territory and the regional differences, we conclude that the main TV channels who broadcast nationwide play a very significant role in the forming of national identity. Therefore, TV becomes the main force for propaganda and political promotion (Cole, 1985).

Since 2003-2004, the results of Russian elections have been quite predictable. However, the most recent elections were noticeably different, because they included subsequent protest movements. As a result, during the electoral campaigns, the media showed a growing interest in the political process, even after voting. The major Russian channels had a large number of segments in their programs, especially current events programs, dedicated to the elections as well as to the street politics.

Major modern media of general interest, addressed to mass audiences, cannot afford a stressed political partisanship. Such channels need to represent the entire width of the political spectrum. According to McChesney, modern commercial media, being in fact manipulated by large owners, creates and actively cultivates the idea of "objective journalism" (McChesney, 2000). Finally, the commercial system of political representation is based on giving more or less attention to this or that political force in its coverage. This model is called "agenda" (McCombs \& Shaw, 1972) and its derivative models are called "spiral of silence" (Noelle-Neumann, 1984) or "gatekeepers" (Shoemaker, 1991).

The main purpose of this paper is to analyse the representation of federal elections by the top three Russian channels. We focus on the content structure of television broadcasting using a variety of quantitative and qualitative methods.

The present study is based on the method of content analysis performed by a team from the media communications faculty of the National Research University Higher School of Economics (Moscow). Two ways of TV recording were coded during the Duma election campaign in 2011 and the presidential campaign in 2012. Each news story was coded by tone, region, mentioned persons, organizations, etc.

To understand the nature of the coverage of the 2011-2012 Federal election campaigns by the leading Russian television channels, it is necessary to consider the following circumstances. In the 1990s the major Russian media was controlled by various oligarchic groups. In particular, ORT (now - the First channel) in the second half of the 1990s was controlled by businessman Boris Berezovsky. NTV was founded in 1993 by Vladimir Gusinsky. RTR (now - Russia-1) belonged to state media holding VGTRK. The coverage of different political parties and candidates during election campaigns could vary significantly. For example, such differences during the Duma campaign in 1999 are described in Fedorov (2000).

After the presidential election in 2000, Berezovsky and Gusinsky were forced to leave Russia. They sold their television businesses to the structures close to the Kremlin. As a result the coverage of politics in Russia by major TV channels changed, becoming 


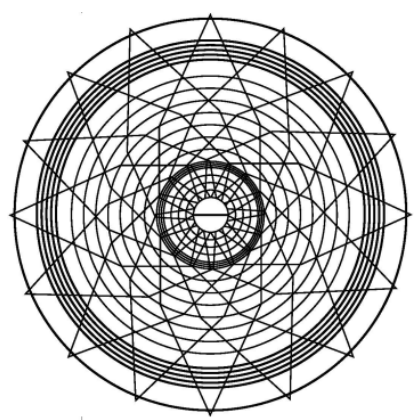

more coherent. There can be some stylistic differences, but not in estimates or stresses. The focus of the television channels as it is shown in Davydov and Davydova (2006), Davydov and Dutov (2007) was moved to government as a fighter for national interests against various opponents, external as well as internal. At the same time in the 2000s some changes in electoral politics were made, which in general limit electoral competition. For example, the gubernatorial elections were cancelled, the line "against all" in ballots was declined, observers were constrained to register at polling stations only from participating parties, etc. In general, the role of major TV channels during electoral campaigns moved from involved political actors to remote observers.

This paper is structured as follows: the first section represents the theoretical background of the content analysis and the results of such research in Russia and other countries. The second section proposes general characteristics of themes, tones and mentioned persons. The third major part of this paper outlines the features of the presidential election and the state election for Duma. Section four provides a description of protest movement representation as well as supporting street actions. The last section offers some discussion and concluding comments.

\section{Survey Methodology}

The basic quantitative characteristics of television used in this paper were obtained in the research project, and are implemented using content analysis. This study was carried out in 2011-2012 as part of the project of the media research faculty in the National Research University Higher School of Economics (HSE), Russian Economic School, Berkman Center for Internet and Society Studies at Harvard University and the University of Glasgow. The research methodology was created by Sergey Davydov (HSE) and Sarah Oates (University of Glasgow).

Issues from evening information programs on major TV channels were selected for the study: "Vremja" at 21:00 (Pervyjkanal), "Vesti" at 20:00 (Rossija-1) and "Segodnja" at 19:00 (NTV). In addition, the sample included weekly summary programs "Voskresnoe vremja" (Pervyj kanal), "Vesti v subbotu", "Vestinedeli", (Rossija-1), "Segodnja. Itogovaja programma" (NTV), and also issues on weekly analytical programs, talk shows and infotainment, including "Pozner", "Prozhektorperishilton", "Grazhdanin Gordon" (Pervyjkanal), "Central'noe televidenie" and "NTVshniki” (NTV).

Audiovisual texts were selected for the two periods: three weeks before and three weeks after the Duma election (November 14 to December 25, 2011), four and a half weeks before and two weeks after the presidential elections (February $4^{\text {th }}$ to March $16^{\text {th }}, 2012$ ). The total volume of processed data was 303 television programs (149 in the first wave of the study, 154 in the second) with a total time of 171 hours 47 minutes and 59 seconds. This includes 3097 stories of twelve different types: 1492 in the first wave and 1605 in the second. More information about the analysed corpuses is shown in Table 1. 


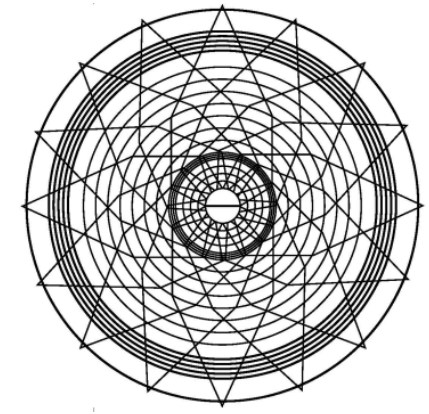

\section{[Scientific Articles]}

Davydov S., Logunova O.

The representation of the federal elections of 2011 and 2012 in Russia by the major national television channels

Table 1. Overview of the sample text content analysis

\begin{tabular}{|c|c|c|c|c|c|c|c|c|c|c|c|}
\hline \multirow[t]{2}{*}{ № } & \multirow[t]{2}{*}{ Program } & \multicolumn{4}{|c|}{ TV channel First wave } & \multicolumn{3}{|c|}{ Second wave } & \multirow[b]{2}{*}{$\begin{array}{l}\text { Number } \\
\text { of issues }\end{array}$} & \multirow[b]{2}{*}{$\begin{array}{l}\text { Number } \\
\text { of plots }\end{array}$} & \multirow[b]{2}{*}{ Duration } \\
\hline & & & $\begin{array}{l}\text { Number } \\
\text { of issues }\end{array}$ & $\begin{array}{l}\text { Number } \\
\text { of plots }\end{array}$ & Duration & $\begin{array}{l}\text { Number } \\
\text { of issues }\end{array}$ & $\begin{array}{l}\text { Number } \\
\text { of plots }\end{array}$ & Duration & & & \\
\hline 1 & Vremja & $\begin{array}{l}\text { Pervyj } \\
\text { kanal }\end{array}$ & 36 & 424 & $18: 24: 57$ & 38 & 411 & 19:06:27 & 74 & 835 & $37: 31: 24$ \\
\hline 2 & $\begin{array}{l}\text { Voskresnoe } \\
\text { vremja }\end{array}$ & $\begin{array}{l}\text { Pervyj } \\
\text { kanal }\end{array}$ & 6 & 48 & $05: 55: 12$ & 6 & 52 & 05:13:30 & 12 & 100 & 11:08:42 \\
\hline 3 & Pozner & $\begin{array}{l}\text { Pervyj } \\
\text { kanal }\end{array}$ & 6 & 27 & 05:03:25 & 5 & 24 & 04:12:36 & 11 & 51 & 09:16:01 \\
\hline 4 & $\begin{array}{l}\text { Prozhektorp } \\
\text { erishilton }\end{array}$ & $\begin{array}{l}\text { Pervyj } \\
\text { kanal }\end{array}$ & 6 & 49 & 02:12:44 & 5 & 34 & $02: 37: 12$ & 11 & 83 & $04: 49: 56$ \\
\hline 5 & $\begin{array}{l}\text { Grazhdanin } \\
\text { Gordon }\end{array}$ & $\begin{array}{l}\text { Pervyj } \\
\text { kanal }\end{array}$ & 0 & 0 & 00:00:00 & 4 & 16 & 03:31:28 & 4 & 16 & 03:31:28 \\
\hline 6 & Vesti & Rossija-1 & 31 & 301 & $15: 45: 28$ & 32 & 350 & 14:09:26 & 63 & 651 & $29: 54: 54$ \\
\hline 7 & $\begin{array}{ll}\text { Vesti } & \mathrm{V} \\
\text { subbotu } & \end{array}$ & Rossija-1 & 6 & 82 & 04:47:05 & 4 & 65 & 03:21:13 & 10 & 147 & 08:08:18 \\
\hline 8 & Vesti nedeli & Rossija-1 & 6 & 70 & 06:09:21 & 6 & 74 & 07:23:06 & 12 & 144 & $13: 32: 27$ \\
\hline 9 & Segodnja. & NTV & 37 & 384 & $14: 16: 17$ & 38 & 437 & 14:06:43 & 75 & 821 & 28:23:00 \\
\hline 10 & $\begin{array}{l}\text { Segodnja. } \\
\text { Itogovaja } \\
\text { programma }\end{array}$ & NTV & 5 & 40 & 03:11:50 & 7 & 80 & $06: 00: 34$ & 12 & 120 & 09:12:24 \\
\hline 11 & NTVshniki & NTV & 5 & 26 & 04:32:12 & 4 & 20 & $03: 25: 20$ & 9 & 46 & $07: 57: 32$ \\
\hline 12 & $\begin{array}{l}\text { Central'noe } \\
\text { televidenie }\end{array}$ & NTV & 5 & 41 & 04:06:01 & 5 & 42 & 04:15:52 & 10 & 83 & $08: 21: 53$ \\
\hline \multicolumn{3}{|c|}{ TOTAL: } & 149 & 1492 & 84:24:32 & 154 & 1605 & 87:23:27 & 303 & 3097 & \\
\hline
\end{tabular}




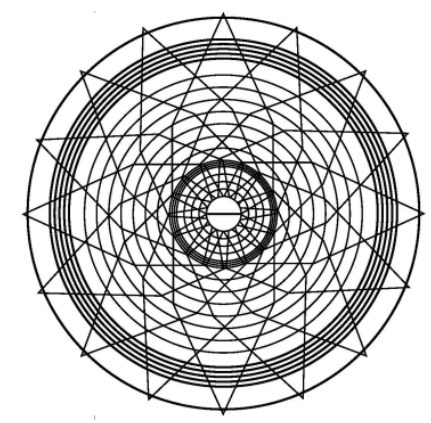

During the project, the following parameters were encoded:

- basic parameters of program (name, channel, release date, etc.);

- time and sequence number of the plot in the TV program;

- geography of scene (regions/countries mentioned in the scene);

- persons who were mentioned, spoke or were shown without mention;

- characters and organizations;

- attitude towards electoral and protest topics;

- visualization and presenter;

- the tone, the importance and attitude of the presenter of the event;

- reference of the plot to the themes (from the list);

- a free-form description of the plot.

In addition, data obtained during previous TV news content analysis studies was used for comparison and to identify trends. First, the project by Sergey Davydov and Natalia Seliverstova "Content analysis of television news in 2004" conducted for the nonprofit organization "Internews". Second, the content analysis of television programs, implemented by the International Institute of Marketing and Social Research "GfK-Rus" in $\mathbf{2 0 0 7}$ for the Fund "Educated Media".

The current comparative analysis was limited by methodology. Comparing the data for 2011 and 2012 with the results of content analysis in 2004 and 2007, we should take into account the methodological differences in all three research projects. Also, in 2004 and 2007, the analysis was not done during the electoral period.

\section{Literature Review}

The changing role of the media in the process of public opinion formation is an important topic in communications research. During the nineteenth century, political communications took place through media whose editorial positions were defined by the interests of certain parties. As a result, every newspaper corresponded to a certain political orientation. In this sense, the media functioned as mediators between political movements and their adherents in the society. According to McChesney, this form of interaction was truly pluralistic, because it allowed the audience to explore the basis of various media reports to get information about the political positions of the various political structures (McChesney, 2000). In fact, each political party had its own channels of mass communication at that time, and the audience was aware of the political orientation of any printed media (Hallin \& Mancini, 2004).

At the next stage a parallelist commercial system was formed. In the context of media business development, it became unprofitable to maintain a strict and hard-edged political position. However, media owners as business people were more inclined to adjust the media in support of right-wing views. A corresponding model of modernity was embodied in which each media source, in one form or another, attempts to reflect or represent the entire width of the political spectrum. Finally, according to 


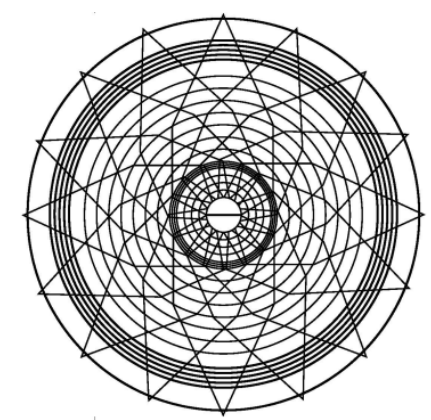

[Scientific Articles]

Davydov S., Logunova O.

The representation of the federal elections of 2011 and 2012 in Russia by the major national television channels

McChesney, modern commercial media actively cultivates the idea of "objective journalism", while journalism is, in fact, manipulated by large owners (McChesney, 2000). Political representation in the commercial media system is based on giving more or less attention to various political forces. This model is called "agenda" (McCombs \& Shaw, 1972) and its derivative models are called "spiral of silence" (Noelle-Neumann, 1984) or "gatekeepers" (Shoemaker, 1991). The agenda model suggests that the media, giving greater or lesser attention to a given topic, forms a certain pattern of social priorities shared by recipients. The spiral of silence model supposes that political actors attempt to publicly articulate the most popular opinion. Finally, the gatekeeper model suggests that certain messages are cut off while the media, journalists and editors act as gatekeepers of information.

Much of the study of media focuses on how it may enhance existing political institutions within a particular country (Linaa, 2006; Lusoli\&Ward, 2006; Wright, 2006). We emphasize the need to understand the role of information and communication technologies (ICTS) within a national context. Measurements of media "freedom" are compiled and publicized around the world, but these assessments are usually more of a projection of a particular national media tradition onto the media system in another country to see how it measures up.

The classic models of the media were developed by Siebert et al. (1963) during the Cold War. In their 1963 classic, Siebert, Peterson and Schramm divided the world's media into four models: libertarian, social responsibility, authoritarian and Soviet. They argued that the libertarian model supported the notion that opinion should be aired freely; the social responsibility model held that media should work proactively to include all segments of society in its coverage; the authoritarian model called for a press completely subservient to the state; and the Soviet press model required that the media support the Marxist-Leninist view of reality. These models have been debated, criticized, labelled as an artefact of the Cold War and sometimes just ignored. However, they remain an important starting point for discussion of the media and the public. All of these models should be treated as "ideal types"(Weber).

According to Hallin and Manchini, one of the central problems of the classic models is that the elements of all of them are evident in many democracies. In their study using the experience of political systems in North America and Europe, they finally devised the liberal model, the democratic corporatist model and the polarized pluralist model (Hallin \& Mancini, 2003). These three models are based on modern-day research and describe how media systems operate today. The Russian media does not fit into any of these models, which is not surprising.

In the wake of the collapse of the Soviet Union in 1991, the new Russian government generally rejected the elaborate media productions of Soviet times. Russians overwhelmingly rejected the idea of "objectivity" or even "balance" in mass media (Oates, 2006). Oates named this model the neo-Soviet model of the media. According to Oates, Russians perceive the media as a political player, generally deployed in the service of their financial and political patrons. In addition, there is a lot of state and 


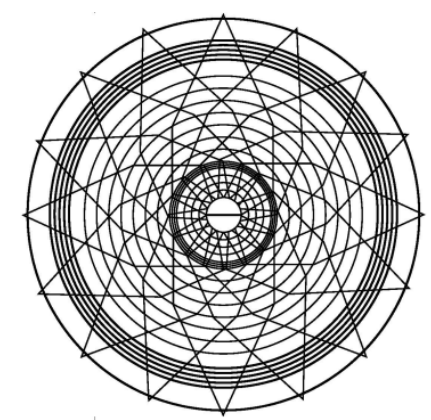

commercial ownership across all levels of print and broadcast media in Russia. However, the most dominant media outlet is television. As a result, the central television stations retain a particular influence both in commercial and political spheres.

Many researchers have drawn attention to this fact. They explain the specificity of the formation of a "people's government" and national identity in Russia by several factors: the Soviet legacy, reproducing a paternalistic model in public institutions (Bagger, 2007), social and cultural crisis after the collapse of the USSR (Sztompka, 1993), the size of area and a wide range of television channels (cable TV in Russia has not received the same distribution as, for example, in the U.S.), regional and social disparities in access to the Internet and other new methods of communication (Zubarevich, 2005). However, all of these researchers make clear that the Russian media is again a tool for the elites (directly or indirectly controlled by the state), rather than a watchdog of the masses (Oates, 2007). A detailed study of the methods of public pressure on editorial policy in Russia was conducted by Koltsova (2006).

The proposed research is based on the methodology of content analysis, which is highly important for complex social studies. Krippendorff (2004) introduces the history and core principles of content analysis, as well as an essential resource for the present study, examines the conceptual and methodological aspects of the method and clarifies the epistemology and logic of the research. Content analysis of television was conducted by research groups twice, in 2004 and 2007, in Russia. Most coding parameters were tested on earlier content analysis projects (Oates, Lee, Kaid\& Berry, 2010; Oates, 2006). Media during the electoral period was researched by Oates, Fedorov, etc.

\section{General characteristics. Themes}

For the most part, the top three Russian TV channels create the national agenda, which is why the themes of their news and analytical programs are so important. They represent current affairs in Russian society and around the world. In the survey, TV stories were divided into four groups in accordance with the sphere of society. The thematic blocks are the following.

Economic issues including a discussion of the Russian budget, inflation, taxes and privatization, international trade, news of the major companies and other topics around the economic situation within the country and abroad.

Political affairs including constitutional reforms, the role of legislative bodies, human rights issues and relations between the central and regional authorities. Formally, this unit should include electoral problems, although in practice this type of subject could be treated as economic, social, etc.

Social issues related to the topic of education, health, culture, science, sports and the activities of various social services. 


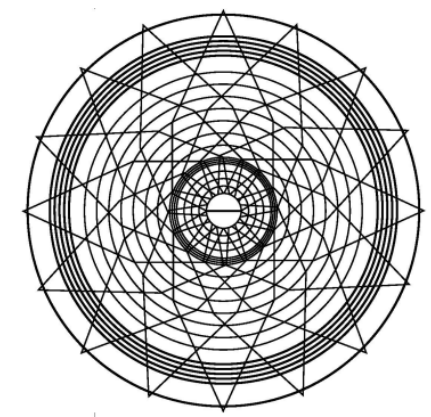

Cultural issues including stories and activities devoted to cultural character. For example, the story of the discovery in the Bolshoi Theatre after reconstruction.

The analysis indicated that stories attributed as social are the largest number. The leadership of news from the social sphere is detected on different levels: for the sample in general, for the first and the second waves and for each of the three TV channels. A similar trend was registered in 2007. The share of stories on economic issues has increased in the last seven years, while the share of stories about cultural life has declined.

Figure 1. The distribution of subjects by theme depending on the data period (\%)

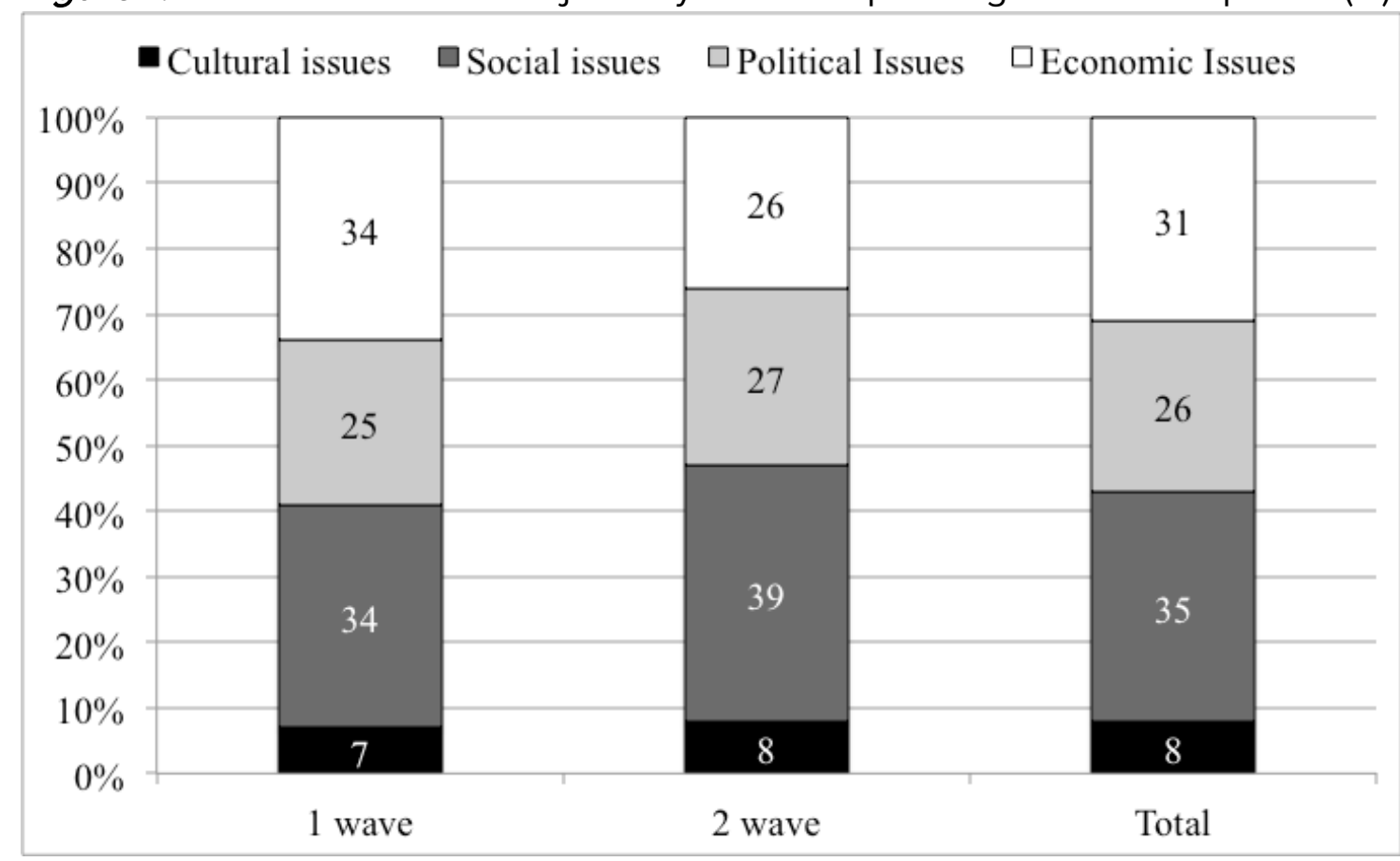

The share of social subjects is 36 percent overall, with a difference between the waves from 34 percent to 39 percent (see Figure 1). Political coverage is very stable; its share stayed within 2 percent over the two time periods. The economic stories show a dynamic shift. During the parliamentary elections the proportion of economic issues was 34 percent, whereas in the period of the presidential campaign it dropped to 26 percent. A change in priorities can be observed in the reduction of such stories. Their proportion equals the proportion of political themes; social issues become favourable. All attention is focused on the social sphere; almost two out of five subjects (39 percent) were devoted to social issues. The number of stories on different social groups (pensioners, children, etc.) increased.

In general, a trend of presenting negative news is detected as negative, not necessarily in tone but in terms of content. A large proportion of the stories are devoted to various kinds of accidents. In the economic sphere, a high proportion of stories related to the economic crisis, corruption and economic crimes appear ("The 


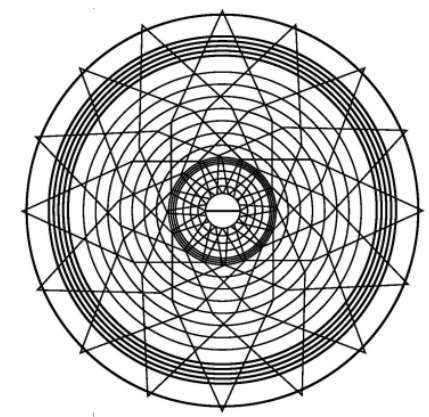

situation with economic debts of Greece", "Report on the environmental threat in the extraction of ore in Russia," etc.). News related to the social sphere discusses problems faced by citizens ("Strong frosts identified budgetary spivvery in housing management companies ", "The problem of counterfeit medical cards took universal character in Russia", "The resettlement of people from emergency buildings began in the village Rose", etc.).

Russian channels primarily tend to present a range of current topics and expert analysis of the problems in the country as a whole, as well as the global situation. Analysis of the scale indicates that almost half of the stories (47 percent) are national news. Regional and international subjects are next in terms of frequency. Interregional events are in last place (less than 1 percent of the analyzed data).

Figure 2. The scale of the events

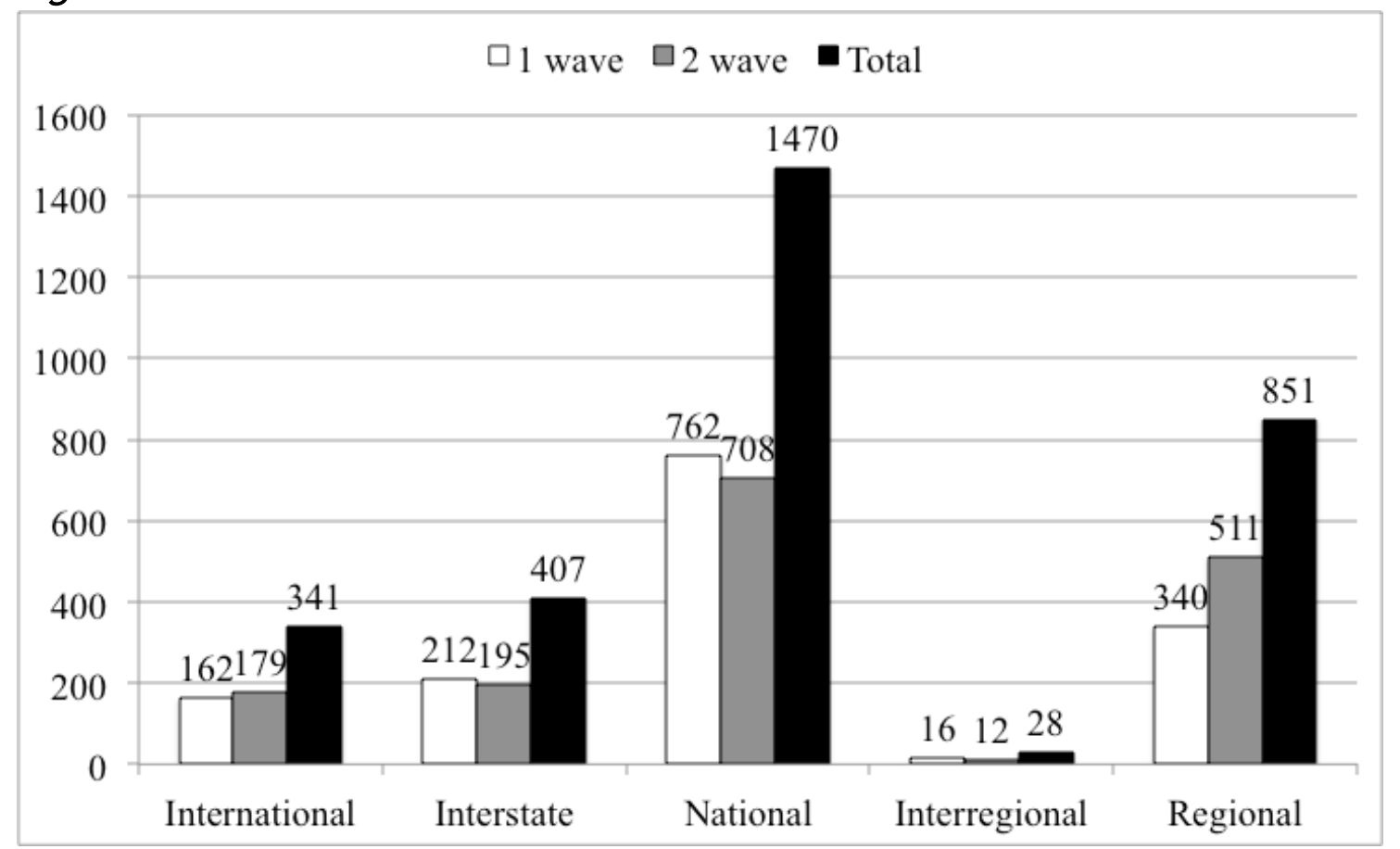

\section{Tones}

The tone of the messages is mainly positive (38 percent) or neutral (35 percent); 10 percent of the data was evaluated as ambiguous reflecting both negative and positive aspects in the video. About 17 percent of subjects were identified as negative. These are so-called "bad news", among which we can distinguish several groups. These include obituaries, stories about natural disasters, accidents, etc. In addition to clearly negative stories, there are a lot of "sad" stories that are not obviously meaningful as entertainment. They raise a variety of social problems, as has been shown above. At the same time, the tone of those stories can be neutral and ambiguous. 


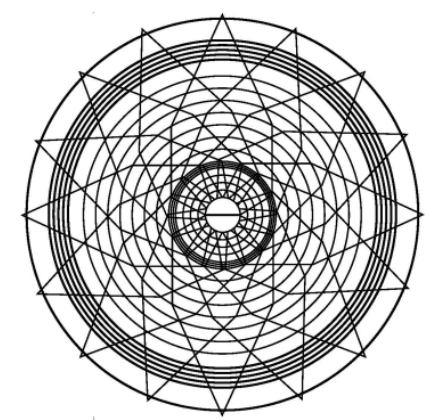

Figure 3. Tones of the TV stories

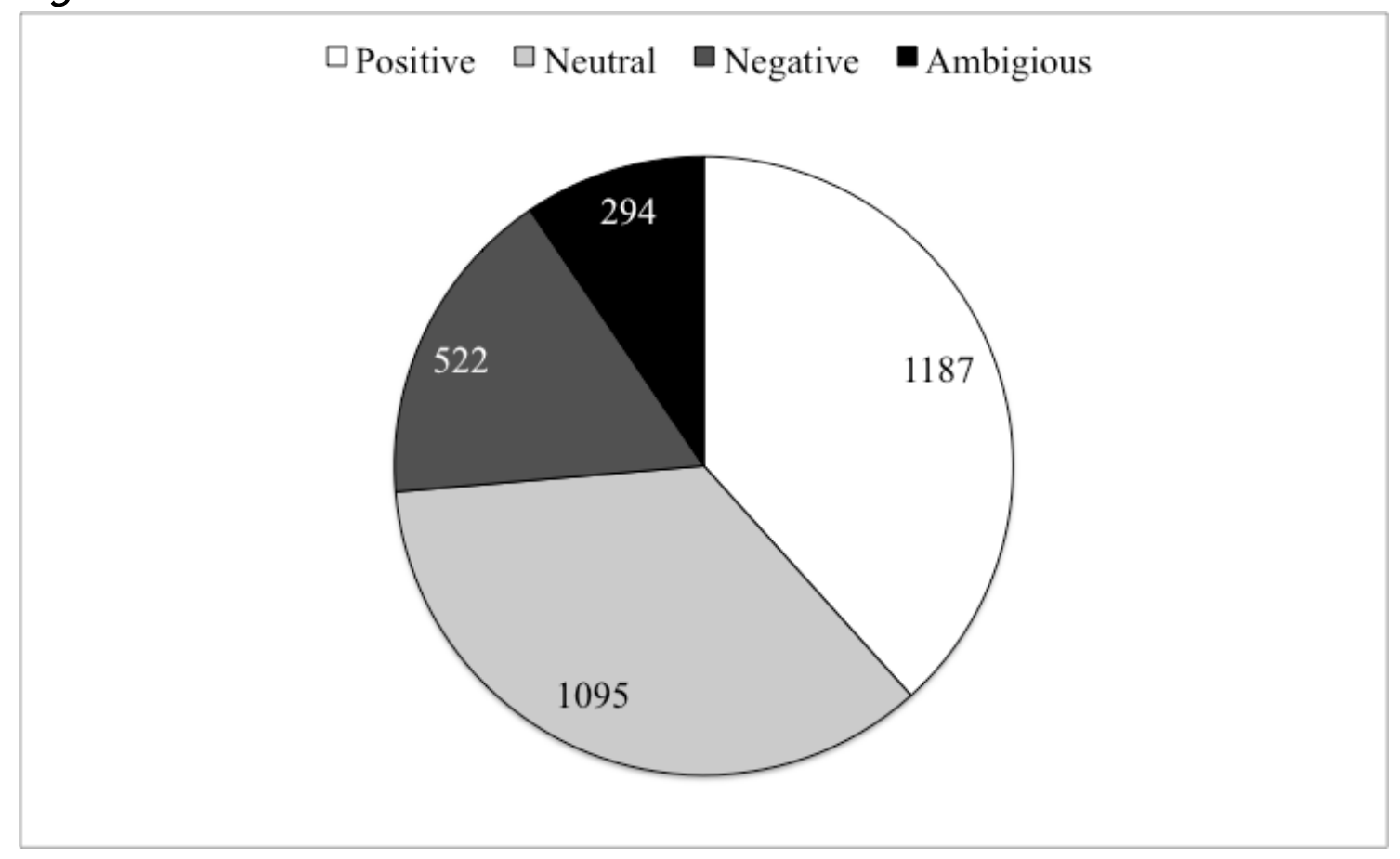

\section{Geography}

Analysis of the geography of informational programs focused on the affiliation with a particular region of the Russian Federation or a foreign country, if the story was devoted to foreign matters. The place of action and country that was mentioned in the story was coded separately.

A comparison between the ratio of internal and external stories in 2011-2012 with 2004 and 2007 shows a clear shift towards internal information (Figure 4). During the analysed period, more than three-quarters of program time was devoted to domestic news and only a quarter devoted to events abroad. The Russian share of information has increased by almost 15 percent compared with earlier survey periods.

Pervyj kanal is the leader in terms of the share of Russian internal information among the three analyzed channels. The share of such stories equals almost 80 percent. In 2004 NTV paid most attention to the Russian regions, while Pervyj kanal and NTV shared the first line in 2007. Rossija-1 pays more attention to foreign topics than the other two channels.

\section{Regions of Russia}

The purpose of nationwide news programs is to provide a full range of current national topics, as well as expert analysis of the problems of society as a whole. Because of its vast territory, it is quite difficult for central television channels to reflect the situation in Russia as a whole. 


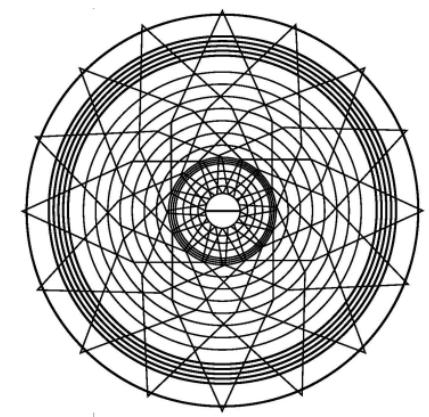

Figure 4. Distribution of news stories on geography in 2004, 2007 and 2011-2012

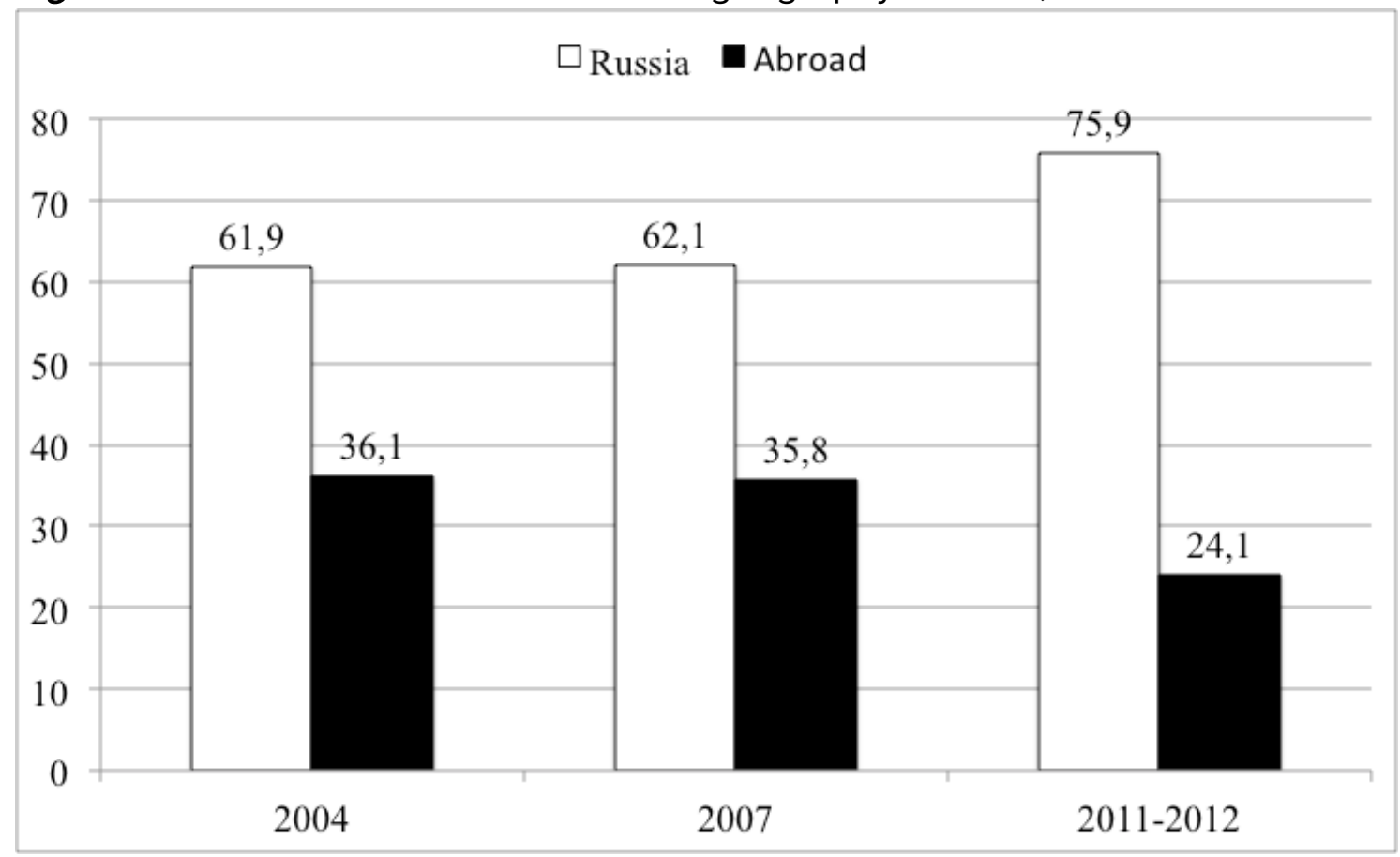

Another challenge is a relatively low level of development of horizontal links between federal subjects of the Russian Federation. Finally, some regions become a scene of news action if they represent examples of events and trends that are relevant for the whole country.

The Russian Federation was identified as the place of action in 2351 internal stories. The leader is Moscow, the capital. In this case the term "Moscow" means the event (news, stories) that took place in Moscow as a region and approximately half the stories take place here (1567 subjects). In 2004 this figure was 28.7 percent; in 2007 it was 28.8 percent. Thus, the proportion of stories taking place in Moscow doubled. In second place in terms of appearance is the Moscow region; it is the place of action for 198 subjects among domestic news, followed by St. Petersburg (59) and the Krasnodar region (48). Table 1 presents the top ten regions selected by frequency of mentions. Last place is shared by two members of the federation: Altai Krai (1) and the Jewish Autonomous Region (1). Information on local areas is represented by local channels, which play an important role in the formation of public opinion. This is a reason for the consistent popularity of regional news television.

The regional focus has shifted over time. Generally, places where extraordinary events and emergencies occured appeared on the TV news and analytical programs more frequently. This can be called the "point of eventness". In our research in 2011-2012, it was the Krasnodar region. There are two main reasons for this. First, the region was frequently mentioned in the context of the up coming Olympic Winter Games in 2014 (tracking of construction and commissioning of the Olympic venues). Second, many 


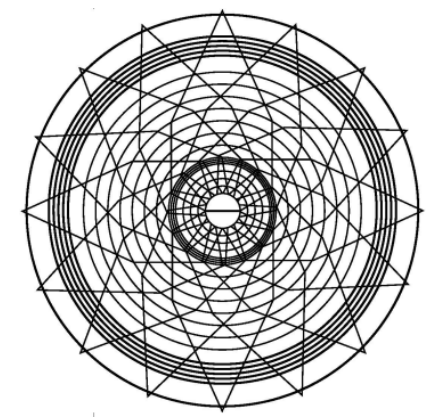

scenes were devoted to litigation in the case of a mass murder in the village of Kuschevskaya. The Republic of Dagestan and the Chechen Republic are also traditional central "points of attention" and have not fallen away in public interest.

Table 2. Appearance of the Russian regions in the news on the top three TV channels (abs.)

\begin{tabular}{|l|l|l|}
\hline $\mathbf{N}^{\mathbf{0}}$ & Regions & Mentions \\
\hline 1 & Moscow & 1589 \\
\hline 2 & Moscow region & 198 \\
\hline 3 & St. Petersburg & 59 \\
\hline 4 & Krasnodar region & 48 \\
\hline & $\begin{array}{l}\text { The Republic of } \\
\text { Dagestan }\end{array}$ & 25 \\
\hline 6 & The Primorskykray & 25 \\
\hline 7 & Sverdlovsk region & 25 \\
\hline 8 & The Chechen Republic & 25 \\
\hline 9 & Volgograd region & 23 \\
\hline 10 & Rostov region & 20 \\
\hline 11 & Krasnoyarsk region & 20 \\
\hline
\end{tabular}

Analysis of the external information allows us to observe similar trends, namely the existence of "eventnesspoints" and "points of attention". As we already noted, the share of foreign events significantly decreased to merely 24 percent. Pervyj kanal has only 20 percent of subjects from abroad while Rossija-1 and NTV have about 26 percent. Compared with the situation in 2004 and 2007, stories from Europe occupied a prominent place. However, we should note that the share of "European" stories grew only in the block of foreign information. In 2007, its share was 11.9 percent and in 2004 it was 9.9 percent. NTV puts a great emphasis on Europe. France and Germany are most frequently mentioned, with each accounting for about 1 percent of the total number of mentions. In addition, Greece can be considered the "point of attention" (0.8 percent) due to the economic crisis in the country and assistance programs from the Europe Union (EU). Thus, Europe is in first place followed by the CIS (the Commonwealth of independent states) countries. Almost 5 percent of Russian channels' stories are from those regions, and this is similar to 2007. Compared with 2004, the proportion of stories from the CIS fell by one half.

America follows Europe and the CIS in the number of subject-references and occupies 3.8 percent of TV stories. The majority of the stories from this part of the world are directly connected to the United States (3.2 percent). In comparison with previous years, this index has decreased (in 2004 it was 5.8 percent; in 2007 it was 9.8 percent). 


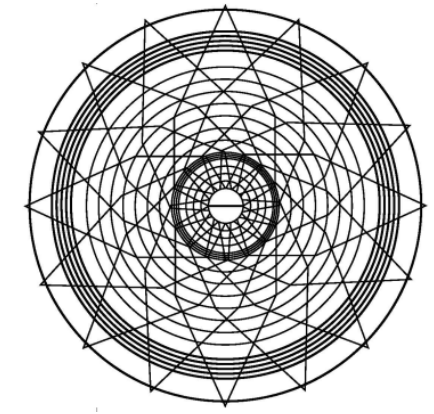

The most notable decrease is associated with the Middle East. In 2004, it accounted for about 16 percent of broadcasting time (especially in connection with the war in Iraq). Time share for this region is about 3 percent now, holding steady since the data of 2007. A more detailed distribution of news by region is represented in Table 3.

Table 3. Distribution of news stories by region (channels, in abs. and \%)

\begin{tabular}{|c|c|c|c|c|c|c|c|c|}
\hline \multirow[t]{2}{*}{ Regions } & \multicolumn{2}{|c|}{ Pervii kanal } & \multicolumn{2}{|c|}{ Rossija-1 } & \multicolumn{2}{|l|}{ NTV } & \multirow[b]{2}{*}{ Abs. } & \multirow[b]{2}{*}{$\%$} \\
\hline & Abs. & $\%$ & Abs. & $\%$ & Abs. & $\%$ & & \\
\hline Russia & 858 & 79,08 & 697 & 73.99 & 796 & 74.39 & 2351 & 75.91 \\
\hline Moscow & 166 & 15.30 & 145 & 15.39 & 278 & 25.98 & 1567 & 19.02 \\
\hline $\begin{array}{l}\text { Rest of the } \\
\text { world }\end{array}$ & 227 & 20.92 & 245 & 26.01 & 274 & 25.61 & 746 & 24.09 \\
\hline CIS & 46 & 4.24 & 50 & 5.31 & 58 & 5.42 & 154 & 4.97 \\
\hline Europe & 82 & 7.56 & 72 & 7.64 & 108 & 10.09 & 262 & 8.46 \\
\hline France & 12 & 1.11 & 8 & 0.85 & 13 & 1.21 & 33 & 1.07 \\
\hline Germany & 7 & 0.65 & 12 & 1.27 & 14 & 1.31 & 33 & 1.07 \\
\hline $\begin{array}{l}\text { The } \\
\text { Americas }\end{array}$ & 25 & 2.30 & 43 & 4.56 & 50 & 4.67 & 118 & 3.81 \\
\hline USA & 22 & 2.03 & 39 & 4.14 & 45 & 4.21 & 106 & 3.42 \\
\hline $\begin{array}{l}\text { Southwest } \\
\text { Asia }\end{array}$ & 38 & 3.50 & 46 & 4.88 & 29 & 2.71 & 113 & 3.65 \\
\hline Egypt & 8 & 0.74 & 8 & 0.85 & 3 & 0.28 & 19 & 0.61 \\
\hline $\begin{array}{l}\text { Eastern } \\
\text { Asia }\end{array}$ & 6 & 0.55 & 8 & 0.85 & 7 & 0.65 & 21 & 0.68 \\
\hline Africa & 11 & 1.01 & 16 & 1.70 & 13 & 1.21 & 40 & 1.29 \\
\hline $\begin{array}{l}\text { The world } \\
\text { in general }\end{array}$ & 8 & 0.74 & 3 & 0.32 & 7 & 0.65 & 18 & 0.58 \\
\hline TOTAL & 1085 & 100 & 942 & 100 & 1070 & 100 & 3097 & 100 \\
\hline
\end{tabular}




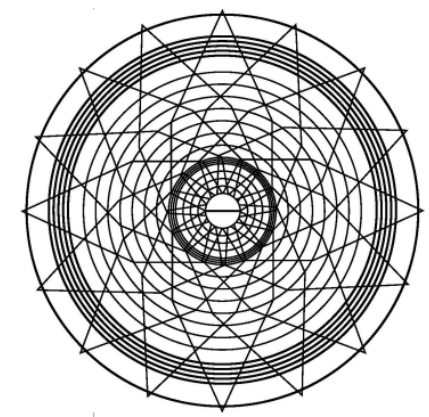

\section{[Scientific Articles]}

Davydov S., Logunova O.

The representation of the federal elections of 2011 and 2012 in Russia by the major national television channels

Thus, Moscow and other regions of Russia occupy most TV broadcasting time; the share of foreign news has now reduced to only about a quarter of stories. Moscow remains the main place of information, followed by Europe, CIS countries and the United States.

\section{Persons}

According to the analysis, over a thousand various persons were mentioned in the selected programs, exactly 1004. The mentioned persons were found in 1556 stories, approximately half of the 3097 stories in general. In accordance with the terms of content analysis, we could mark a few people in one subject. Eventually 3082 mentioned people were recorded (1484 in the first wave and 1598 in the second). The participants were divided into the following categories:

- persons who were mentioned;

- persons who spoke;

- persons who were shown without being mentioned.

Among the group of persons who spoke, politicians occupied the first position with an overwhelming majority of about 70 percent, while economists had a share of 12 percent, representatives of the cultural sphere had 9 percent, and 8 percent were representatives of the social sphere. This trend generally holds and does not significantly change with time. Figure 5 demonstrates this.

Figure 5. Distribution of persons by sphere

-Economic sphere $\square$ Political sphere $\square$ Social sphere $\square$ Cultural sphere $\square$ Other

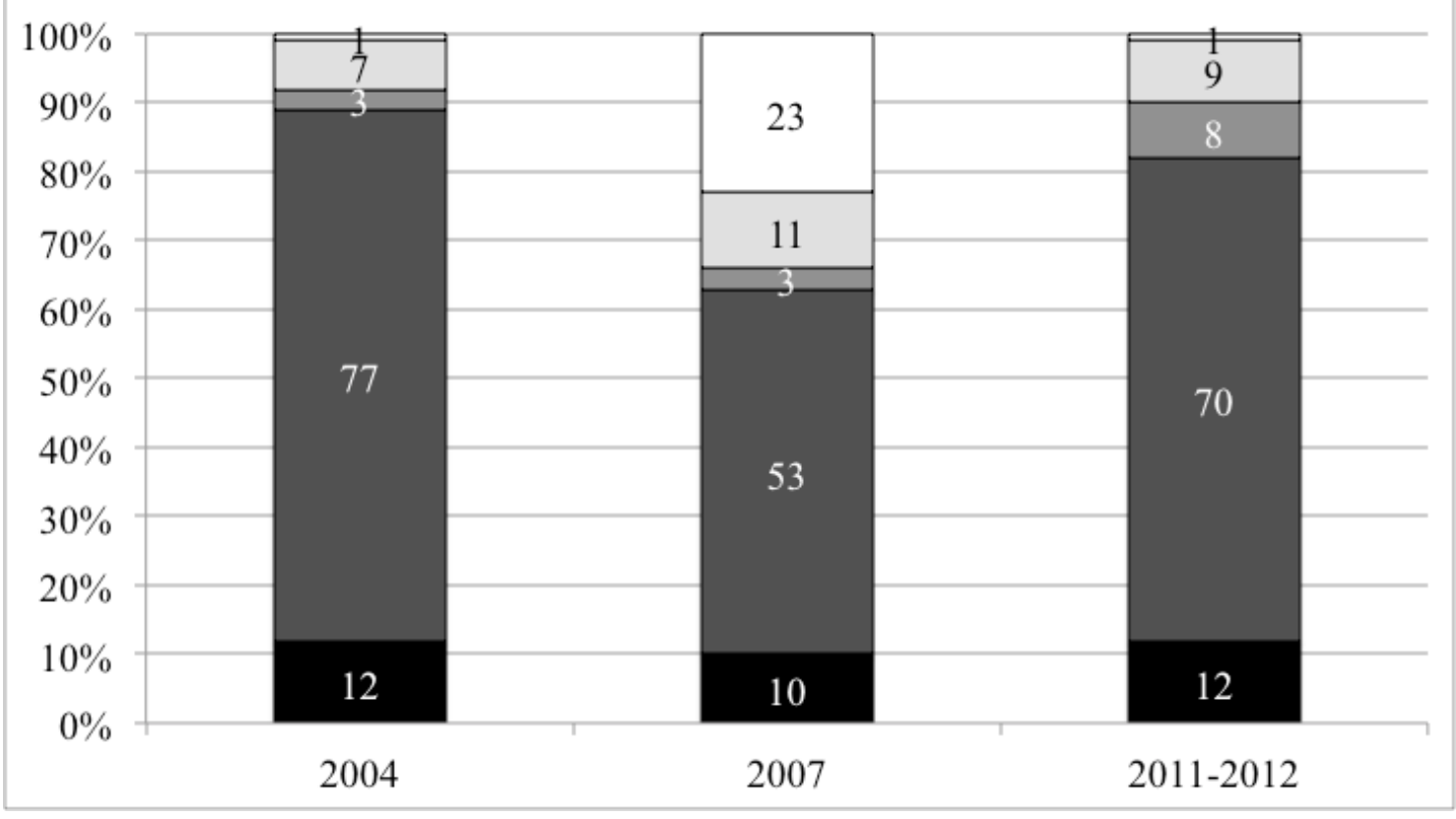




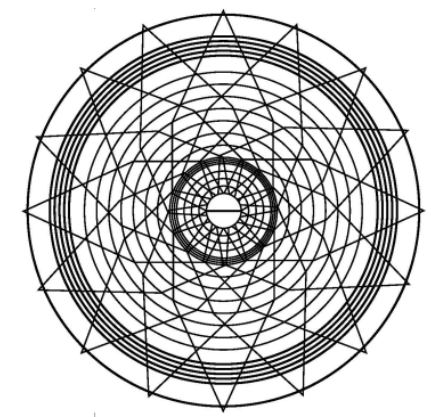

As shown above, political topics are not dominant in the news. However, the main actors of the Russian informational field are politicians. The ten persons most frequently mentioned are representatives of the political sphere of society. Participants of political life are key figures in all kinds of stories. They are directly connected with political themes and other matters of economic, cultural and educational problems and so on. They are primarily the heads of state, presidential candidates and leaders of major Russian political parties as well as government representatives (see Figure 6). Putin and Medvedev are the unconditional leaders, followed by other participants of the electoral process, such as Zyuganov, Prokhorov, Zhirinovsky, Mironov, Churov and Yavlinsky. The prisoner and ex-oligarch Khodorkovsky stands out for his history. It is worth noticing that two persons from Russian history, Stalin and Yeltsin, were also mentioned; all other persons are currently living. Certainly, this indicates the trend of increasing attention on political persons during the period of electoral campaigns. The election becomes a key topic on the agenda.

The tone of the mentions of most persons generally coincides with the tone of the information as a whole (see Figure 6). The first two places (Putin and Medvedev) are mentioned in a positive context about 40 percent of the time and in a neutral context about 37 percent of the time. Pay attention to their presentation of the group of four persons (Gennadiy Zyuganov, Mikhail Prokhorov, Vladimir Zhirinovsky and Sergey Mironov). The proportion with a negative tone is half compared to the average share of the data. Curiously, Khodorkovsky is primarily mentioned in a neutral context.

Figure 6. The stories' tones of top mentioned persons

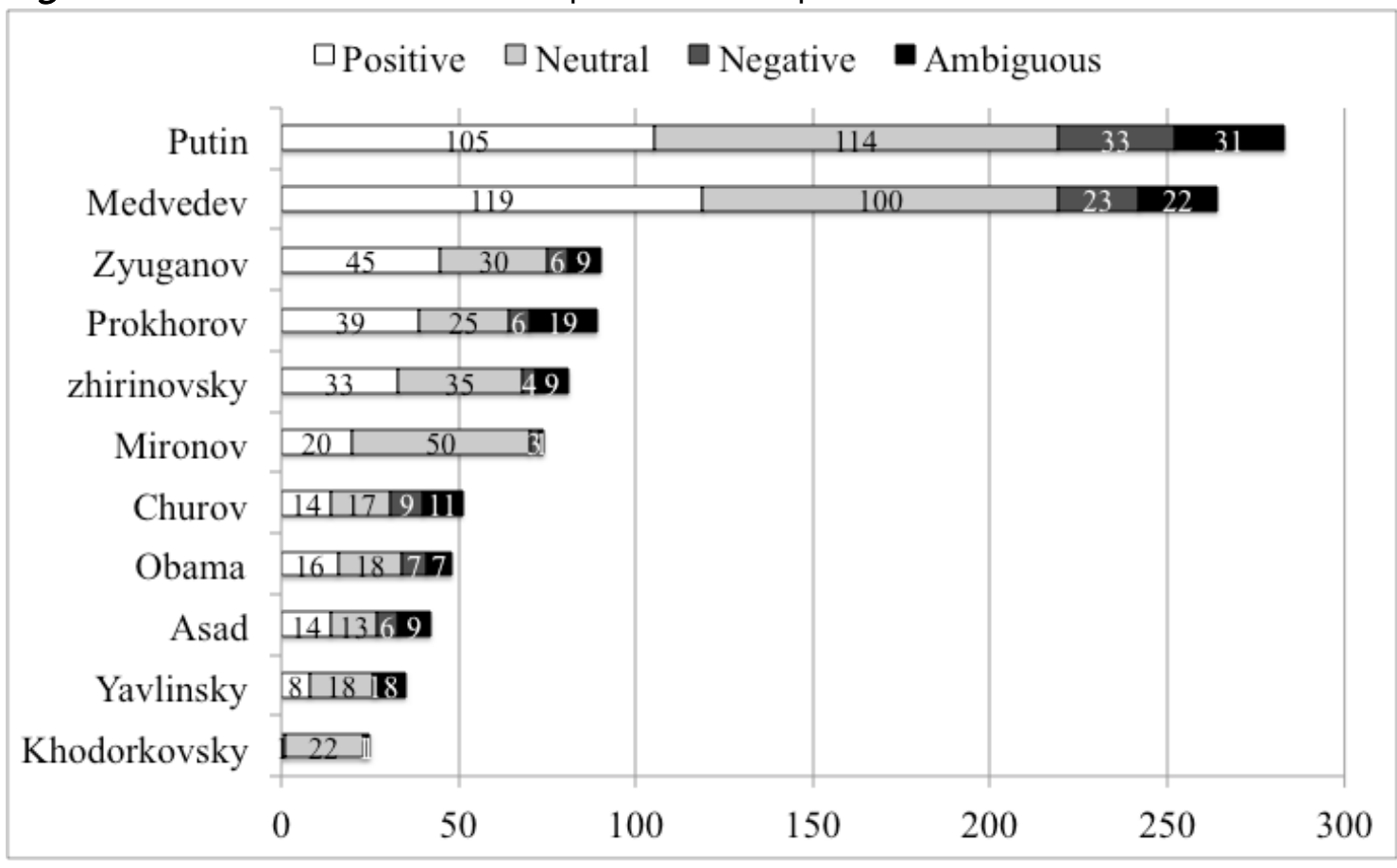




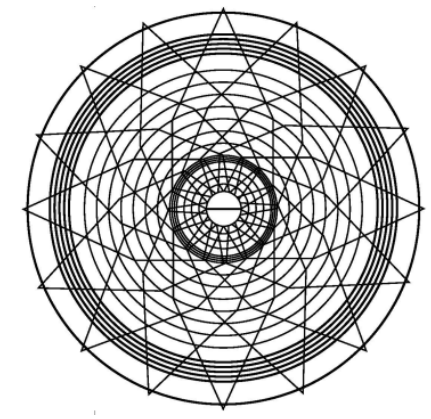

Analysis of the mentioned persons' distribution by geographic region indicates the predominance of local characters (60 percent). The remaining mentions are divided among the leaders of foreign countries: European countries (France, the UK, Germany, Italy, etc.), Latin and North America (mainly the U.S.A.) and representatives of the Middle and Far East (China, Iraq, Egypt, etc.).

The analysis of the persons who spoke in the frame demonstrates a large number of subjects that do not contain such references. Stories in which a geographic region was not mentioned account for 56 percent (1742) of cases. While stories in which the location of the person is mentioned account for about 1355 stories. Actually they have 3018 recorded persons, 2.2 percent of mention to each subject on the average. Who is often shown speaking on the TV channels? Table 4 demonstrates the frequency of the character with the performance depending on the type of program.

Table 4. Distribution of persons speaking depending on the type of TV program

\begin{tabular}{|c|c|c|c|c|c|c|c|}
\hline \multirow{2}{*}{ No. } & \multirow{2}{*}{ Names } & \multicolumn{2}{|l|}{ Total } & \multicolumn{2}{|c|}{ Infotainment } & & \\
\hline & & $\%$ & $\begin{array}{l}\text { Number of } \\
\text { mentions }\end{array}$ & $\%$ & $\begin{array}{l}\text { Number of } \\
\text { mentions }\end{array}$ & $\%$ & $\begin{array}{l}\text { Number of } \\
\text { mentions }\end{array}$ \\
\hline 1 & Vladimir Putin & 10.71 & 319 & 1.54 & 7 & 12.29 & 312 \\
\hline 2 & Dmitrij Medvedev & 10.21 & 304 & 2.42 & 11 & 11.43 & 293 \\
\hline 3 & Sergei Mironov & 3.93 & 117 & 1.10 & 5 & 4.37 & 112 \\
\hline 4 & Vladimir Zhirinovsky & 3.93 & 117 & 2.20 & 10 & 4.17 & 107 \\
\hline 5 & Grigoriy Zyuganov & 3.49 & 104 & 0.66 & 3 & 3.94 & 101 \\
\hline 6 & Mikhail Prokhorov & 3.32 & 99 & 3.74 & 17 & 3.20 & 85 \\
\hline 7 & GrigoriyYavlinsky & 0.97 & 29 & 0.00 & 0 & 1.13 & 29 \\
\hline 8 & Vladimir Churov & 0.84 & 25 & 0.00 & 0 & 0.98 & 25 \\
\hline 9 & Vladimir Ryzhkov & 0.84 & 25 & 1.76 & 8 & 0.66 & 17 \\
\hline 10 & Dmitrij Rogozin & 0.81 & 24 & 0.00 & 0 & 0.88 & 24 \\
\hline 11 & $\begin{array}{l}\text { Patriarch of Moscow } \\
\text { Kirill }\end{array}$ & 0.77 & 23 & 0.44 & 2 & 0.82 & 21 \\
\hline 12 & Sergej Naryshkin & 0.71 & 21 & 0.00 & 0 & 0.82 & 21 \\
\hline 13 & Boris Nemtsov & 0.60 & 18 & 0.22 & 1 & 0.66 & 17 \\
\hline
\end{tabular}

Leading positions are occupied by Putin and Medvedev, each constituting more than 10 percent of the total number of references. Other active politicians follow them with 


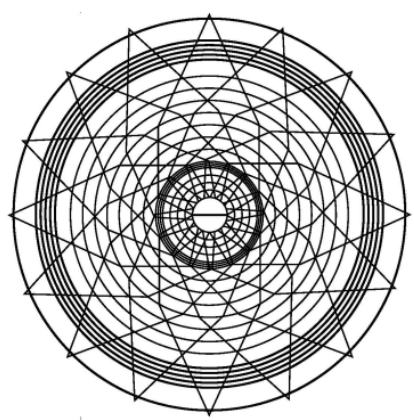

a noticeable lag. Presidential candidates Mironov, Zhirinovsky, Zyuganov and Prokhorov receive only a third of the mentions Putin and Medvedev receive. If we look at the first thirty persons, we discover that all of them are connected with the political sphere. They are Russian high-ranking officials or representatives of the opposition and the politicians of other countries. In addition, we see the representatives of show business (Sobchak, Pugacheva), journalists (Leontiev, Parfenov) and public persons (Kurguinjan, Patriarch of Moscow Kirill) in this list, but their appearance is also related to the political context.

The list of main speakers in the news programs almost completely coincides with the list of persons mentioned without direct speech. The first eight positions coincide exactly. There is a direct correlation between the frequency of mentions in the news and the frequency of speech for the same person. The list of speakers in the analytical programs and talk shows is markedly differed from the list of speakers in television news (see Table 4). Prominent places are occupied by Prokhorov and Zhirinovsky, who are always happy to participate in such programs. In addition, the gap between the leaders and the pursuers in this case is not so noticeable. Journalists (Leontiev, Kandelaki, Parfenov, etc.) and linkmen (Tolstaya, Sobchak, etc.) express their position and discuss and comment on each other's statements, which is quite typical for this format.

\section{The features of the Duma and presidential elections}

The TV agenda during the electoral period has several features. First, we should note the number of stories on the topic. During and immediately after the Duma campaign, the share of stories on the election was 19 percent of the total and 27 percent in terms of time. The share of indirect mentions of electoral issues was 10 percent of stories and 14 percent by time. This topic of the election accounted for approximately one third of all mentions.

The distribution of stories among the TV channels generally depends on their policies. Pervii kanal pays comparatively more attention to the state informational policy, NTV has positioned itself as free TV, while Rossiya-1 is positioned as the "main channel of the country". This channel has special time for programs produced at the local level. All these features influenced the coverage during the Duma electoral campaign. The number of subjects among channels confirms this fact, and is presented in Figure 7.

We find the greatest number of stories dedicated to elections on Rossiya-1. This channel is the leader by the number of stories, despite the fact that it only has daily and weekly news, excluding other programs of socio-political content in comparison with the other two channels. It is followed by Pervyi kanal and NTV. Statistics on the distribution of time shows a different situation. Here, leadership belongs to the NTV channel, namely to analytical programs and talk shows "NTVshniki" and "Central Television". They occupy 43 percent of output, which is a significant portion of the 


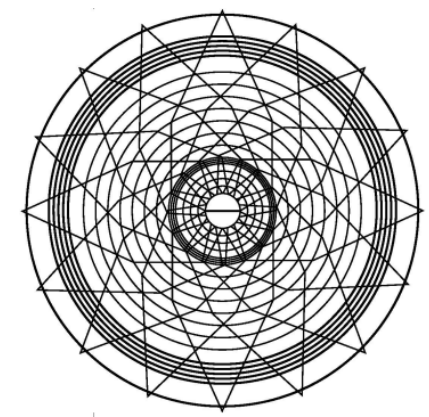

[Scientific Articles]

Davydov S., Logunova O.

The representation of the federal elections of 2011 and 2012 in Russia by the major national television channels

total time. This is primarily due to the specifics of the program, which supposes a long time on air compared to the daily news.

Figure 7. The distribution of parties and their leaders

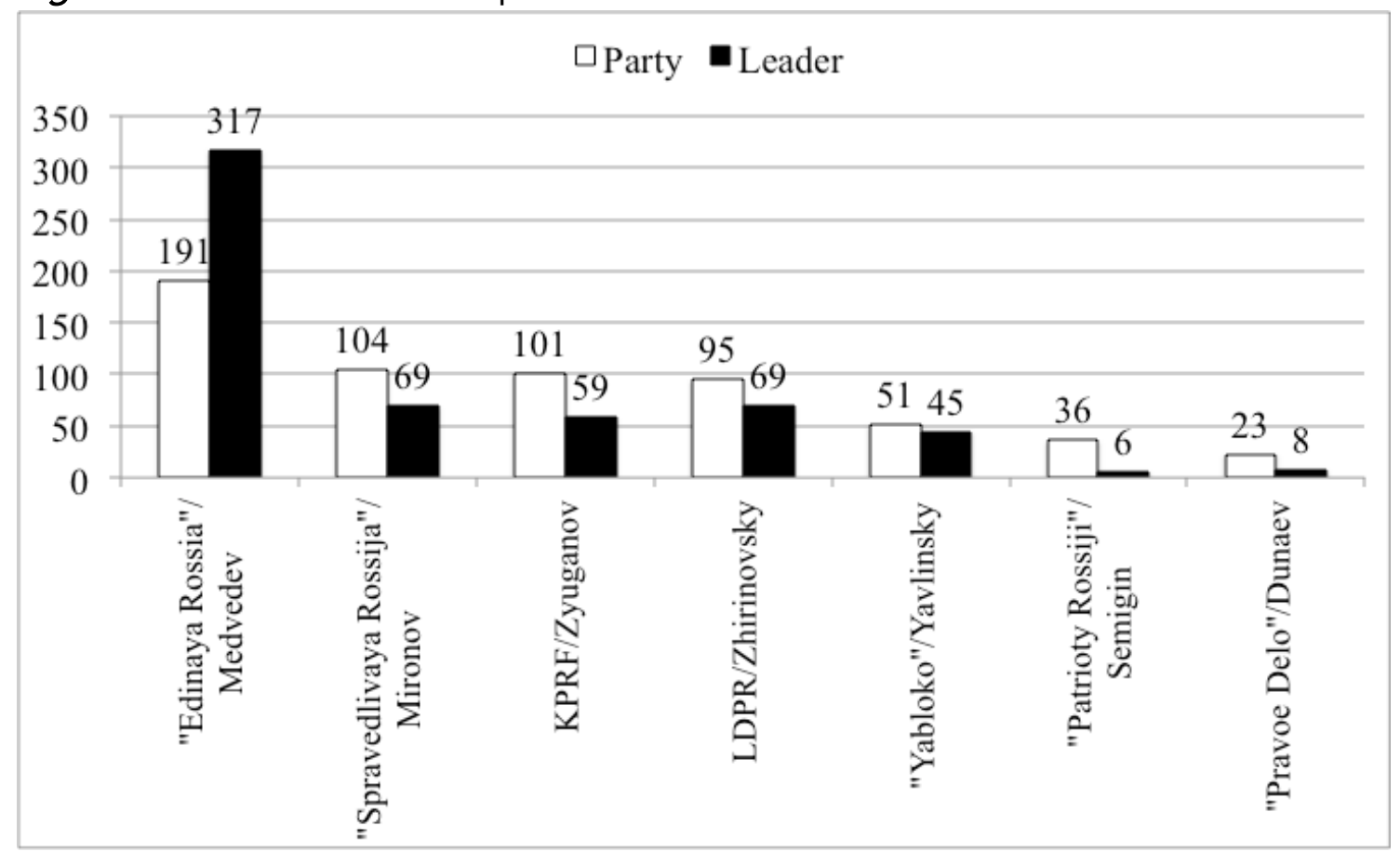

This study has shown that the theme of the State Duma elections is a major event during this period. A sufficient number of stories, namely 601 , or about 40 percent of the total amount of this wave mention the political parties; 573 subjects mention the leaders of these parties. Figure 7 illustrates the relationship between the parties and their leaders in terms of mentions. First place belongs to the party United Russia, which received the largest number of stories on its programs or simple mentions in connection to meetings with voters. Then the Spravedlivaya Rossiy, the Communist Party and the Liberal Democratic Party follow. These four parties are relevant in the political life of Russian society today.

The comparative analysis shows the distribution of the party leaders' mentions. Dmitry Medvedev is in first place. The number of references from the nearest competitor is five times less. This is explained by his combining the post of leader of the party United Russia and the president of the Russian Federation. This fact means that the number of references will be significantly greater than for any other candidates. Zyuganov, Sergei Mironov and Vladimir Zhirinovsky shared second place with an equal number of votes. On the one hand they are successful politicians, on the other hand, this is due to their long presence in the media, and as a result they have a strong personal "brand". Yavlinsky fell behind in the race. Semigin and Dounaev are in last place without significant rates. 


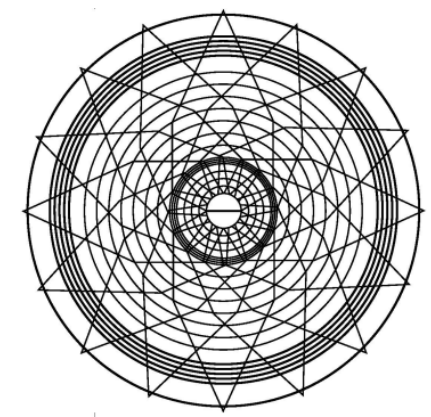

The distribution of time among parties looks exceptionally lopsided. Figure 8 illustrates the relationship of subjects in which the party was mentioned with all parties, with one or more parties, or alone. United Russia is the leader in terms of mono-stories and has about half the total number of mentions. Other parties, for instance "Patriots of Russia", were primarily mentioned in stories which were devoted to all parties. They therefore served as the backdrop for the political struggle.

Figure 8 . The ratio of stories by participants

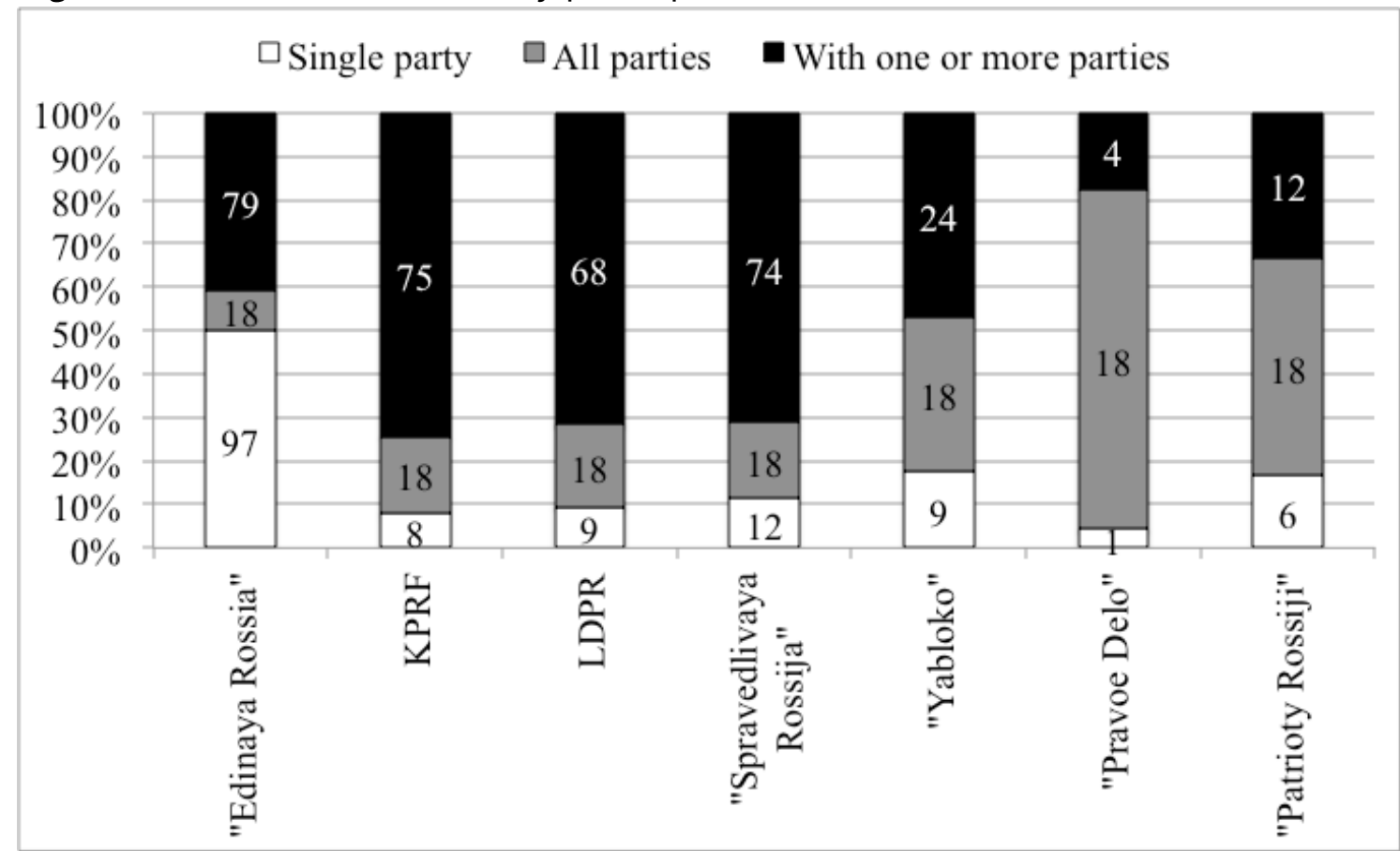

In summary, the vast majority of references (candidates and organizations) belong to the party in power. This demonstrates the administrative command of communication model, the model where the candidate fully utilizes power resources.

During the presidential campaign, indicators of direct and indirect references to the election were 22 percent in the first wave and 9 percent in the second wave, according to the number of subjects, and 30 percent in the first wave and 9 percent in the second wave according to time. These numbers are almost identical. The structure of the number of presidential candidate's mentions is illustrated by Figure 9. It demonstrates a tripling of Putin's media activity just before and during the presidential elections. Moreover, none of his opponents even come close to his indicators. This illustrates the tendency of media dependency on the state.

Putin's team use TV resources to form an image of the national leader as a strong politician who has the support of thousands of people, including well-known personalities. A great number of stories include interviews with famous artists expressing approval for Vladimir Putin. In addition, we account for the growing number of stories about the rallies supporting government activity. 


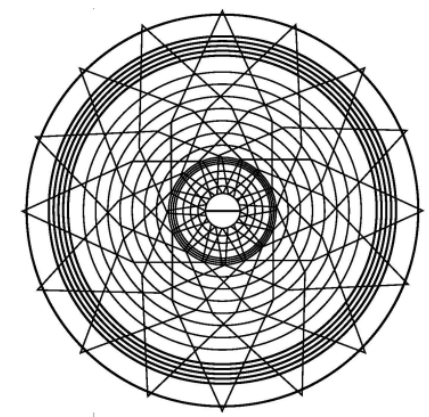

Figure 9. Mentions of presidential campaign candidates

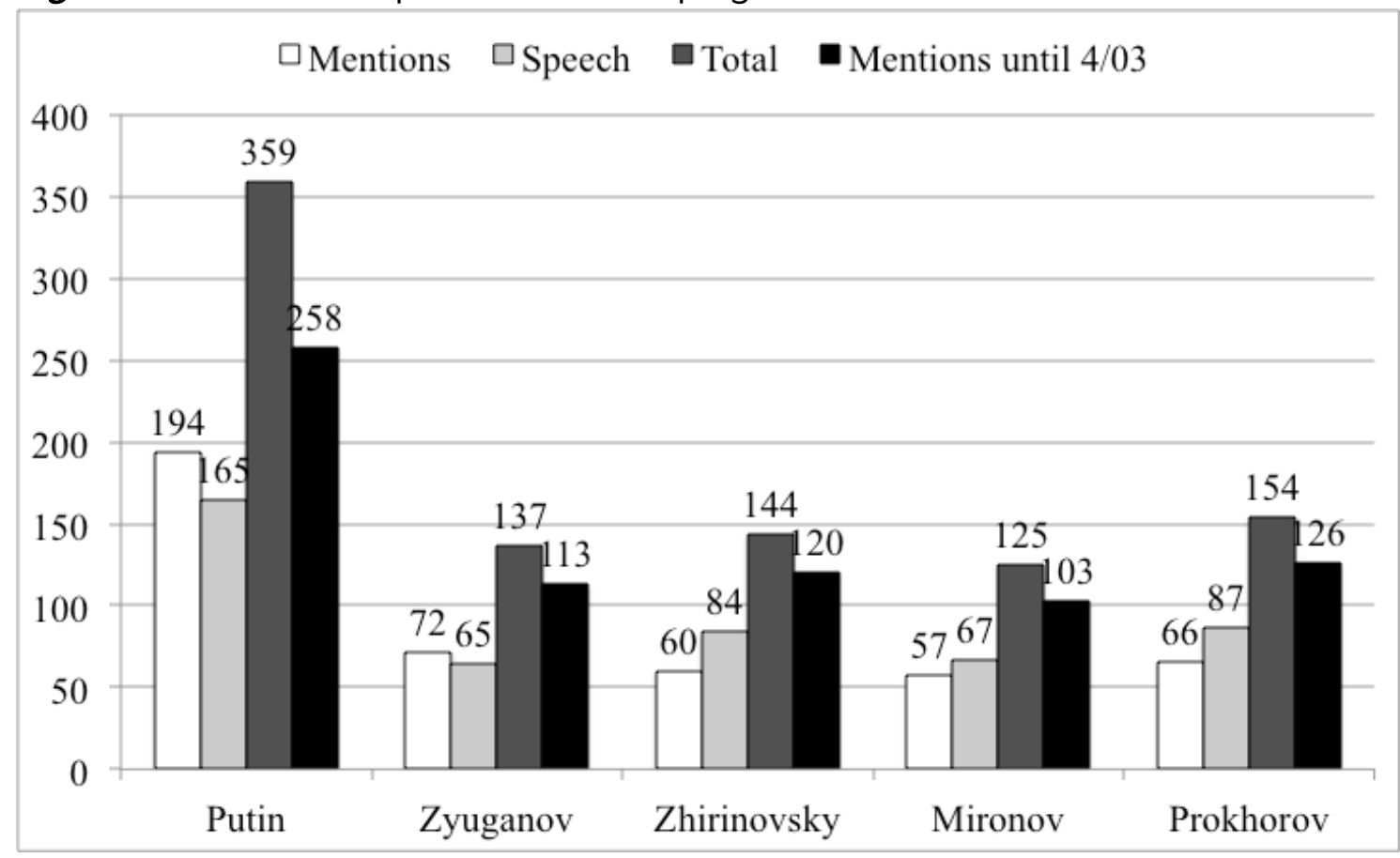

The results of the content analysis have shown that the activity of television references to the Duma and presidential election campaigns on Russian television have a largely imitative character. The illustration of candidates and parties was reduced to pure mentions of the activities of Dmitriy Medvedev and Vladimir Putin, predominantly in connection with their activities in the posts of, respectively, the president and the prime minister. Other participants of electoral campaigns have fewer mentions. Moreover, we have not found the unique dependence of the frequency of occurrences of one or another from opposition or authority. Therefore, we assume that the role of these people is not as great as the political elite from the point of view of those who set the agenda of the federal channels.

\section{Protest movements}

The number of stories about protest activity grew significantly (almost doubled) from the parliamentary to the presidential campaign. However, if we look at the overall time of the stories the numbers stay relatively consistent over the time periods. That is, the narrative of protest rally activity during and after the presidential campaign are significantly shorter and that influences to the depth and objective coverage.

At the same time, the amount and time of plots about rallies in support of the government significantly increased. The number of plots where two different types of movements are correlated with each other within a single narrative increased three times (11 to 44). Simultaneously, the number of subjects with a direct mention of the protests increased, while, conversely, their time decreased. The percentage of 


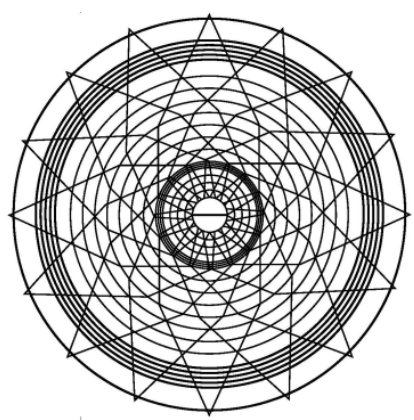

subjects evaluating protests positively was higher in the first wave (32.2 percent) than in the second (29.8 percent).

Therefore, we conclude that the subject of protests begins to increase not in the reports (longer by time) but in news stories or oral communications (shorter and more neutral) that refer to the subject. Journalists predominantly evaluated rallies in support of the current government, which has been particularly active in the second period during the presidential campaign, in a neutral and vague manner. Journalists probably tried to reconcile their own beliefs with the need to comply with state force, causing emotional uncertainty.

\section{Conclusion}

This paper has examined the role of media during the electoral campaigns in Russia in 2011 and 2012 as well as specific features of the Russian television model, which can be clearly observed during political events. The Duma and presidential electoral campaigns were chosen as a representative political events for analysis. The present study was designed to determine the tendencies of informational programs from different perspectives.

In general, these findings suggest that the main themes of informational programs are social and economic issues. Political topics are in third place. However, generally, the electoral campaign becomes a key topic of the TV agenda because, despite the national status of the event, the main hero of the modern Russian news program is the politician.

The second major finding is that politicians are most popular in terms of persons mentioned in the news. This investigation has shown that Putin and Medvedev as representatives of authority were the most frequently mentioned during the period of analysis. The main actors of the informational field are the members of government, leaders of major political parties and the opposition movement, candidates for the presidential position and their supporters.

The results of the research support the observed trend of presenting negative news on the major channels. A large part of the news stories are devoted to various kinds of accidents. The marked trend demonstrates the representation of contemporary Russia in the context of a depressive and conflicted environment. According to the programs, approximately all the important areas of society are in crisis: politics, economy and the social sphere and family relations. The reverse side of social life depression is catastrophic and severe. The main characters have become survivors, victims, terrorists and criminals. These stories cause a surge of emotions and wide public resonance. Russian daily news is meaningful in the segment of public and political broadcasting. Therefore, television passively translates the mood emerging in the mass consciousness.

Another of the more significant findings to emerge from this study is the national character of news. Moscow and regions of Russia take the most time, while the share 


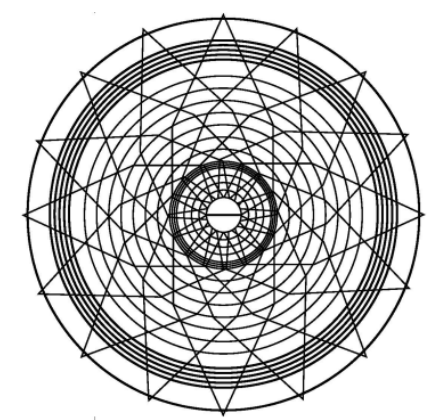

[Scientific Articles]

Davydov S., Logunova O.

The representation of the federal elections of 2011 and 2012 in Russia by the major national television channels

of foreign news has diminished. Moscow remains the main source of information, occupying about half of the stories, followed by Europe, CIS countries and the United States.

The results of this study reveal that the Duma and presidential election campaigns on Russian television have a largely imitative character. Approximately a third of the total data by time and number of stories is devoted to this topic. The elections became the major theme during this period. The majority of references belong to the party in power. This demonstrates the administrative type of communication model where the candidate fully uses administrative resources if he or she has access to them.

Generally, television tends to isolate protest movements from the mass audience despite the fact that the actions of the opposition immediately after the parliamentary elections and the presidential elections of 2011 and 2012 had a definite place in the television news agenda. This isolation was carried out through a small representation of opposition politicians compared with favourites, being mainly the actions of the executive branch through a change in the representation of television genres from long to short forms of reports.

We assume that political representation built across mentions of political parties, their leaders and representatives of various social strata in television news, which are still the most important types of coverage to inform the public about political life in Russia. Additionally, television is the most significant media in Russia and is often directly or indirectly controlled by the government. All news channels are under strict editorial control, which translates the request of power mostly represented by the administration of the president.

The present study makes several noteworthy contributions. First, the method used for this research may be applied to other themes. Second, the obtained results allow us to point out some features in the informational coverage of Russian elections in 2011 and 2012. In both cases the informational policy of the top three TV channels was quite similar. The struggle of politicians and parties in the media environment had an imitational nature, and in both instances the political process was noticeably revived the day after voting.

The electoral cycle of 2011-2012 has become a starting point for a new media landscape. The methods and tools of election information support became the foundations for the new "media system" and the "new consensus" that exists now and the state is totally based on it. The best way to confirm this is to conduct the same study in 2017-2018 for comparison. It will allow us to trace the tendency of development and transformation the trends described above. 


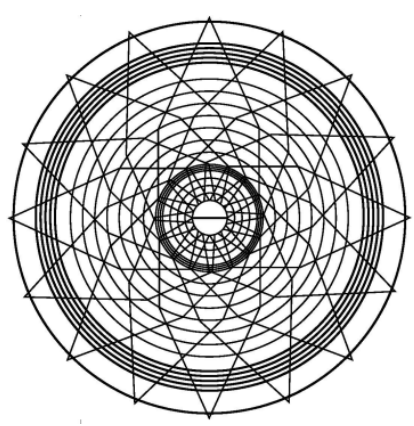

[Научные статьи]

Давыдов С.Г., Логунова О.С. Репрезентация федеральных выборов 2011 и 2012 гг. в России крупнейшими федеральными телеканалами

\section{REFERENCES:}

Bagger, H. (2007). The Study of History in Russia during the Post-Soviet Identity Crisis, Scando-Slavica.

Cole, R. (1996). "Good relation": Irish Neutrality and the Propaganda of John Betjeman 19411943. Eire-Ireland 30(4), pp. 33-46.

Davydov S. \& Davydova T. (2006). Formirovanie massovoj psikhologii cherez sredstva massovoj kommunikatsii. Psikhologicheskie aspekty politicheskogo protsessa vo «vtoroj putinskoj respublike». Pod red. E.B.Shestopal. Moscow.: Aspekt Press.

Fedorov I.G. (2000). Kontent-analiz soobsheniy sredstv massovoy informatsii: izmerenie politicheskoy prostrastnosti. SMI I politika v Rossii. Moscow, pp. 56-65.

Grushin B. A. Massovoe soznanie. Moscow, 1987.

Hallin, D. \& Mancini, P. (2004). Comparing Media Systems: Three Models of Media and Politics. Cambridge: Cambridge University Press.

Kippendorff, K. (2004). Content analysis: introduction to its methodology. Sage.

Koltsova, O. (2006). News media and power in Russia. London: Routledge.

Linaa Jensen, Jacob (2006). The Minnesota E-Democracy Project: Mobilising the Mobilised? In Sarah Oates, Diana Owen and Rachel K. Gibson (eds.) The Internet and Politics: Citizens, voters and activists. London, Rutledge: pp. 59-79.

Lusoli, Ward and Stephen Ward (2006). Hunting Protestors: Mobilisation, Participation and Protest Online in the Countryside Alliance. In Sarah Oates, Diana Owen and Rachel K. Gibson (eds.) The Internet and Politics: Citizens, voters and activists. London, Rutledge: pp. 80-99.

McChesney, R. (2000). Rich Media, Poor Democracy: Communication Politics in Dubious Times. New York: The New Press.

McCombs, M. \& Shaw, D. (1972). The Agenda-Setting Function of Mass Media. Public Opinion Quarterly, 36 (2), pp. 176-187.

Neuendorf, Kimberly A. (2002). The content analysis guidebook. Sage.

Noelle-Neumann, E. (1984). The spiral of silence: Public opinion-our social skin. Chicago: The University of Chicago Press.

Oates, S. (2006). Television, Democracy and Elections in Russia. London: Routledge. 


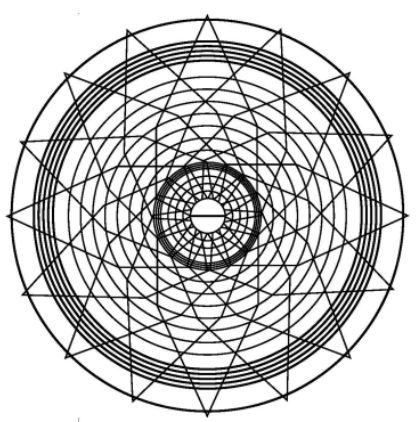

\section{[Scientific Articles]}

Davydov S., Logunova O.

The representation of the federal elections of 2011 and 2012 in Russia by the major national television channels

Oates, S., Lee Kaid, L. \& Berry, M. (2010). Terrorism, Elections, and Democracy: Political Campaigns in the United States, Great Britain, and Russia. London: Palgrave Macmillan.

Oates, S. (2007). The New-Soviet Model of the Media. Europe-Asia Studies, 59 (8): pp. 127997.

Oates, S. (2013). Revolution Stalled. The Political Limits of the Internet in the Post-Soviet Sphere. Oxford University Press.

Shoemaker, P. (1991). Gatekeeping. Newbury Park: Sage.

Siebert, Fred S., Peterson, Theodore \& Schramm,Wilbur (1963). Reprinted 1994. Four Theories of the Press. Chicago: University of Illinois Press.

Sztompka P. (1993). The Sociology of Social Change. London: Wiley-Blackwell.

Wright, S. (2006). Design matters: The Political Efficacy of Government-Run Discussion Boards. In Sarah Oates, Diana Owen and Rachel K. Gibson (eds.) The Internet and Politics: Citizens, voters and activists. London: Rutledge, pp. 80-99.

Davydov S.G., Dutov A.G. (2007). Soderzhanie vechernego televizionnogo jefira v 2007 godu. Rossijskoe televidenie: mezhdu sprosom i predlozheniem. Vol. 2 / Pod red. Kachkaevoj A.G., Kirija I.V. Moscow: Jelitkomstar. pp. 6-87. 


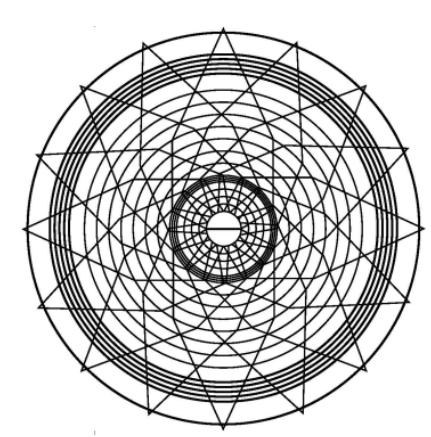

\title{
РЕПРЕЗЕНТАЦИЯ ФЕДЕРАЛЬНЫХ ВЫБОРОВ 2011 И 2012 ГГ. В РОССИИ КРУПНЕЙШИМИ ФЕДЕРАЛЬНЫМИ ТЕЛЕКАНАЛАМИ
}

\author{
Давыдов С.Г. \\ Кандидат философских наук, доцент Департамента \\ медиа, факультета коммуникаций, медиа и дизайна \\ Национального исследовательского университета \\ «Высшая школа экономики» (Москва) \\ sdavydov@hse.ru \\ Логунова О.С. \\ Кандидат социологических наук, доцент кафедры \\ общей социологии Департамента социологии \\ факультета социальных наук Национального \\ исследовательского университета «Высшая школа \\ экономики» (Москва) \\ ologunova@hse.ru
}

\section{Аннотация:}

Предлагаемая статья основана на результатах контент-анализа, целью которого было исследование информационных программ трех крупнейших российских телеканалов («Первый», «Россия-1» и «НТВ») во время выборов в Думу 2011 года, а также во время президентской избирательной кампании 2012 года. В рамках исследования было проведено сравнение новостных выпусков, основных сообщений и политической направленности государственных телеканалов, выбранных стратегий для освещения выборов. Именно политические кампании 2011 и 2012 года в России вызвали наибольший отклик среди граждан Москвы позже эти волнения были охарактеризованы как «протесты на болотной площади», а затем, после президентской кампании, как «Марш несогласных». Результаты исследования демонстрируют тематические и контекстуальные свойства передач, тоны сообщений, а также упомянутых лиц. Показано, что освещение предвыборной кампании было по большей части имитацией. Правящая партия («Единая Россия») и кандидат от партии власти (Владимир Путин) были показаны преимущественно как официальные лица при исполнении должностных обязанностей, что давало им определенные преимущества. Между позициями разных телеканалов относительно политического процесса не было никаких существенных различий. В обоих случаях политическая активность россиян заметно увеличивалась после голосования: в ноябре 2011 в форме протестных демонстраций, а затем в марте 2012 в форме не только демонстраций протеста, но и демонстраций поддержки.

В рамках исследования был произведен анализ освещения деятельности всех основных политических партий России и их лидеров («Единая Россия», «КПРФ», «Справедливая Россия», «ЛДПР», «ЯБЛОКО», «Патриоты России» и «Правое дело»). 


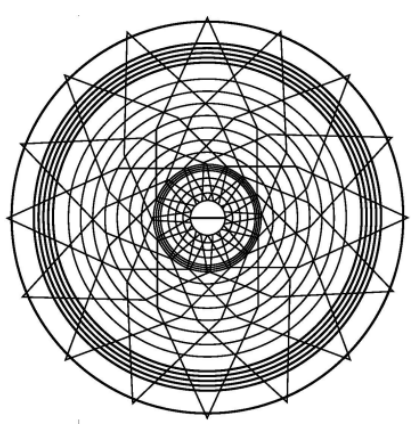

[Scientific Articles]

Davydov S., Logunova O.

The representation of the federal elections of 2011 and 2012 in Russia by the major national television channels

Ключевые слова: контент-анализ, Российское телевидение, выборы в России, Путин, «Единая Россия»

\section{БИБЛИОГРАФИЯ:}

Давыдов С., Давыдова Т. (2006). Формирование массовой психологии через средства массовой коммуникации. Психологические аспекты политического процесса во «второй путинской республике». Под ред. Е.Б. Шестопал. Москва: Аспект Пресс.

Давыдов С.Г., Дутов А.Г. (2007). Содержание вечернего телевизионного эфира в 2007 году. Российское телевидение: между спросом и предложением. Том 2. Под ред. Качкаевой А.Г., Кирии И.В. Москва: Элиткомстар. сс. 6-87

Грушин Б. А. Массовое сознание. Москва, 1987.

Федоров И.Г. (2000). Контент-анализ сообщений средств массовой информации: изменение политической пристрастности. СМИ и политика в России. Москва, сс. 56-65.

Bagger, H. (2007). The Study of History in Russia during the Post-Soviet Identity Crisis, Scando-Slavica.

Cole, R. (1996). "Good relation": Irish Neutrality and the Propaganda of John Betjeman 19411943. Eire-Ireland 30(4), pp. 33-46.

Hallin, D. \& Mancini, P. (2004). Comparing Media Systems: Three Models of Media and Politics. Cambridge: Cambridge University Press.

Kippendorff, K. (2004). Content analysis: introduction to its methodology. Sage.

Koltsova, O. (2006). News media and power in Russia. London: Routledge.

Linaa Jensen, Jacob (2006). The Minnesota E-Democracy Project: Mobilising the Mobilised? In Sarah Oates, Diana Owen and Rachel K. Gibson (eds.) The Internet and Politics: Citizens, voters and activists. London, Rutledge: pp. 59-79.

Lusoli, Ward and Stephen Ward (2006). Hunting Protestors: Mobilisation, Participation and Protest Online in the Countryside Alliance. In Sarah Oates, Diana Owen and Rachel K. Gibson (eds.) The Internet and Politics: Citizens, voters and activists. London, Rutledge: pp. 80-99.

McChesney, R. (2000). Rich Media, Poor Democracy: Communication Politics in Dubious Times. New York: The New Press. 


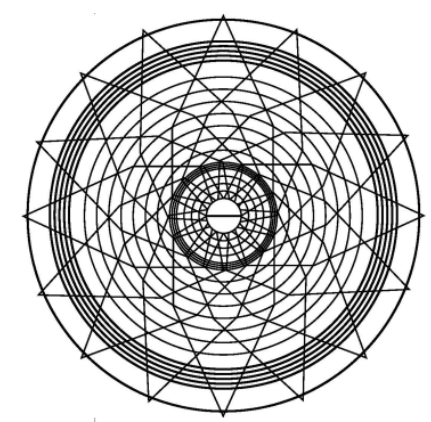

McCombs, M. \& Shaw, D. (1972). The Agenda-Setting Function of Mass Media. Public Opinion Quarterly, 36 (2), pp. 176-187.

Neuendorf, Kimberly A. (2002). The content analysis guidebook. Sage.

Noelle-Neumann, E. (1984). The spiral of silence: Public opinion-our social skin. Chicago: The University of Chicago Press.

Oates, S. (2006). Television, Democracy and Elections in Russia. London: Routledge.

Oates, S., Lee Kaid, L. \& Berry, M. (2010). Terrorism, Elections, and Democracy: Political Campaigns in the United States, Great Britain, and Russia. London: Palgrave Macmillan.

Oates, S. (2007). The New-Soviet Model of the Media. Europe-Asia Studies, 59 (8): pp. 127997.

Oates, S. (2013). Revolution Stalled. The Political Limits of the Internet in the Post-Soviet Sphere. Oxford University Press.

Shoemaker, P. (1991). Gatekeeping. Newbury Park: Sage.

Siebert, Fred S., Peterson, Theodore \& Schramm,Wilbur (1963). Reprinted 1994. Four Theories of the Press. Chicago: University of Illinois Press.

Sztompka P. (1993). The Sociology of Social Change. London: Wiley-Blackwell.

Wright, S. (2006). Design matters: The Political Efficacy of Government-Run Discussion Boards. In Sarah Oates, Diana Owen and Rachel K. Gibson (eds.) The Internet and Politics: Citizens, voters and activists. London: Rutledge, pp. 80-99. 